\title{
Brothels: outlaws or citizens?
}

\author{
Penny Crofts \\ Faculty of Law, University of Technology, Sydney
}

\begin{abstract}
Historically, sex services premises in New South Wales, Australia were regarded and regulated as illegal and disorderly entities; they were policed as outlaws. The Disorderly Houses Amendment Act I995 [NSW] bestowed legal status, providing an opportunity to regulate sex services premises as legal subjects. Despite these reforms, in many areas brothels continue to be regulated more restrictively than other businesses. I argue that this is because, for many, brothels continue to be perceived as outlaws. They are regarded as inherently unlawful, disorderly, and hence warranting and requiring exclusion from the community. I argue that this conception of brothels as outlaws is constructed and reinforced through regulation. In contrast, some local councils and Land and Environment Court decisions have taken up the opportunity to regard and regulate sex services premises as legal subjects or citizens. The conception of sex services premises as citizen imports an existing legal framework, with associated accountabilities, rights and responsibilities. This shift in conception results in people viewing sex services premises differently, experiencing them differently and regulating them differently.
\end{abstract}

\section{Introduction}

Historically, brothels in New South Wales, Australia were regarded and regulated as illegal subjects. As a consequence of the Disorderly Houses Amendment Act I995 [NSW], brothels are now able to operate as legitimate businesses regulated by local councils. Despite these reforms, brothels continue to be treated more restrictively than other legitimate businesses with similar amenity impacts. I argue that this is because brothels continue to be regarded as illegal, as outlaws. This is apparent at the state and local government levels and also in some decisions by the Land and Environment Court. However, the opportunity to regard and regulate brothels as lawful subjects is available and has been explored. In this article, I explore how the regulation of the sex industry might be different if brothels were conceptualised as legal subjects, as citizens rather than as outlaws. These conflicting conceptions structure and reinforce the way we view, experience and regulate sex services premises.

In Part I, I outline Lakoff and Johnson's ideas about the way metaphors alter, form and structure our ways of being in and perceiving the world (I980). In the remainder of the article, I explore how the metaphor of the brothel as outlaw continues to structure the perception and regulation of the sex industry, whilst also demonstrating a glimmer of change in some areas. I juxtapose the implications of the conception of brothel as outlaw - as inherently unlawful, disorderly and requiring expulsion - with the conception of brothel as citizen - a legal subject, with rights and responsibilities, and a contributor to the community.

\section{Part I: metaphors and brothels}

Prior to legislative reforms in 1996, brothels were illegal and subject to closure regardless of whether or not they were well run. The Disorderly Houses Amendment Act I995 [NSW] provided that brothels could operate as legitimate businesses and were to be regulated by local councils. As a consequence, local councils have the power to regulate brothels through their plan-making 
powers, governed by the Environmental Planning and Assessment Act I979 [NSW]. There is a great deal of variation in the way that local councils have exercised their planning powers with regard to sex services premises but, broadly speaking, two different approaches can be identified. The dominant approach conceives of brothels as inherently illegal, whilst the alternative approach conceives of sex services premises as potentially legitimate businesses. In this article, I argue that these different conceptions do not just structure the response to and regulation of sex services premises, but are also reinforced and confirmed by the regulatory approach.

My analysis of the different conceptions of the sex industry is informed by the ideas of Lakoff and Johnson in Metaphors We Live By (I980). Our ordinary conceptual system, in terms of how we think and act, structures what we perceive, how we get around in the world and how we relate to each other. Our conceptual system thus plays a central role in defining our everyday realities. This is not something that we are normally aware of, but we can look at language as a source of evidence for what that system is like. Lakoff and Johnson argue that our conceptual system is fundamentally metaphorical in nature. The essence of metaphor is that we understand and experience one kind of thing in terms of another. Concepts are partially structured, understood, performed and talked about in terms of the metaphor. We act according to the way we conceive of things.

We can analyse language to get a better understanding of what our conceptual systems are like. Metaphor clusters can be traced in speech and writing to analyse the way our thoughts are structured. For example, Lakoff and Johnson analyse the metaphor 'argument is war', a metaphor reflected in our everyday language and in legal texts of all kinds by a wide variety of expressions, such as: 'your claims are indefensible; 'I demolished his argument'; 'He shot down all your arguments'. Lakoff and Johnson assert that we don't just talk of arguments in terms of war, we regard the person we are arguing with as an opponent; we can win and lose arguments. The structure of an argument, attack, defence, counter-attack, etc. reflects and reinforces the concept of war. Thus Lakoff and Johnson assert that the argument is war metaphor is one that 'we live by in this culture; it structures the actions we perform in arguing' (Lakoff and Johnson, I980, p. 4). Lakoff and Johnson suggest that we imagine instead a culture where argument is viewed as dance participants are seen as performers, and the goal is to perform in a balanced and aesthetically pleasing way: 'In such a culture, people would view arguments differently, experience them differently, carry them out differently and talk about them differently.' In that culture, argument would be a discourse structured in dance (p. 5).

Metaphors alter, form and structure our ways of being in and perceiving the world in ways of which we may be unaware. Metaphors are embedded in law, even if speakers do not perceive themselves as speaking metaphorically. The 'law as person' metaphor is expressed extensively in the law - including 'the body of case-law', 'the long arm of the law' and 'in the eyes of the law' (Loughlan, 2006, p. 2I6). Research has been done tracing specific embedded metaphors and expressing the ways in which these metaphors function in various areas of law (Arms, I999; Tsai, 2004; Hibbitts, I994; Thornburg, 1995).

In this article, I rely upon Lakoff and Johnson's ideas about how conceptual metaphors structure and reinforce our perceptions and behaviour to analyse the legal regulation of the sex industry. I will argue that the dominant conceptual metaphor that structures and organises legal regulation is the 'sex industry as outlaw'. The metaphor of outlaw invokes lawlessness, criminality and disorder. The outlaw breaches cherished classification systems, offending against the legal, moral and social order. Through these breaches the outlaw is both contaminated and contaminating. The outlaw's existence poses a challenge to order, generating crime and criminality, fostering corruption, encouraging and causing violation and transgressions of law. The outlaw is literally outside the law, and contact with the outlaw is corrupting and polluting. 
The protection of order requires the exclusion and expulsion of the outlaw from the community. I rely upon historical and current legal examples to demonstrate the understanding, perception and consequence of regarding the sex industry as outlaw.

Throughout the article I juxtapose the metaphor of sex industry as outlaw with sex industry as citizen. I demonstrate how this alternative conception of the sex industry might change our specific ways of thinking about the sex industry and how we act towards it. There is an impressive body of literature on citizenship in political science. The concept of citizenship need not be limited to legal administrative questions. Rather, the term 'citizenship' has great normative and conceptual potential, and can be utilised to develop important new theoretical insights into the participation of the sex industry in society. Citizenship is not just about status, but also about accountability, legitimacy and participation (Carter, 2002). The idea of citizenship has been applied productively to corporations in order to import ideas of participation and social responsibility (Moon, Crane and Matten, 2005; Zadek, 2007; Rubenstein, 2004). The concept has also been extended to sexual citizenship, to frame questions about social membership and belonging (Bell, 2000; Bell and Binnie, 2000). I am drawing upon a fairly basic model of citizenship, emphasising legal status, accountability, legitimacy and the notion of belonging.

I argue that emphasising the concept of brothel as citizen, rather than as outlaw, offers new insight and a normative basis for reconceptualising the sex industry and appropriate regulation. Currently, both approaches are expressed in the legal regulation of brothels in New South Wales. Whilst the dominant metaphor remains the historical conceptualisation of brothel as outlaw, legal materials also express the (potential) idea of the sex industry as citizen. The concepts of outlaw and citizen are not adversarial, but they provide meaningful differences worthy of analysis. I demonstrate the ways in which these metaphors structure and reinforce the regulation of brothels and the different implications.

Concepts about brothels are expressed in many different areas, including news and fiction. In this article I analyse New South Wales legal materials - including legislation, local government regulations, and Land and Environment Court cases. These materials provide a rich source of data and illuminate legal conceptions of sex services premises. As I demonstrate below, the shift towards conceptualising sex services premises has not been fully accomplished in the legal materials. The relevant legislation is diffident, ranging from amendments permitting the legalisation of sex services premises, to statute aimed at hounding 'unlawful and disorderly' brothels out of the community. There is a great deal of disparity amongst local councils, with the majority developing highly restrictive policies aimed at precluding sex services premises from operating in the local government area. Where councils have refused a development application, the applicant might appeal to the Land and Environment Court. The Court has tended to respond to sex services premises as potential legitimate businesses informed by orthodox planning concerns, but there are also a series of cases where restrictive approaches have been adopted, highlighted particularly by the highly influential Martyn v. Hornsby planning principles. ${ }^{\text {I In that }}$ case, Senior Commissioner Roseth outlined the planning principles for locating 'brothels' in the absence of local guidelines. Although the principles are not law, they are highly influential and tend to be applied or referred to in most sex services premises cases, and have also been applied by councils at first instance.

The different approaches to the regulation of the sex industry mean that the terminology is not consistent. The bulk of legislation, regulations and case-law refer to 'brothels' to denote all sex services premises. However, representatives of the sex industry (Brothels Taskforce, 200I) and a small number of councils differentiate between sex services premises based on their size, nature

I Martyn v. Hornsby Shire Council [2004] NSWLEC 6I 4 . 
and services offered. Later in this article, I critique the 'catch-all' category of brothel. However, given its dominance historically and currently, throughout much of this article I utilise the legal terminology of 'brothel', only differentiating between sex services premises when the relevant legal materials do so and where appropriate.

\section{Part II: outlaw versus citizen}

\section{Il/legal status}

A central difference between the outlaw and the citizen is legal status. One of the major characteristics of the outlaw is lawlessness or criminality, whilst a central characteristic of citizenship is legal identity. Historically, brothels were illegal entities, they could not operate legally, they were literally outlaws. The Disorderly Houses Amendment Act I995 [NSW] provided a framework for brothels to operate and be regulated as legitimate businesses, thus granting brothels legal status. However, more than a decade since the reforms, legislation, regulations, and some Land and Environment Court decisions illustrate that the taint of illegality, the perception of brothels as outlaws, remains.

Despite legislative reforms, it is still difficult for brothels to operate legally. The state government has advised local councils that banning brothels is not permitted (Department of Urban Affairs and Planning, 1996). However, many local councils have developed highly restrictive planning regulations that are difficult for brothel owners to meet and are not applied to other businesses with similar amenity impacts. These regulations include strict parking requirements, operating hours, notification requirements, disability access and zoning restrictions. Where brothel owners have appealed council refusals, in many cases the Land and Environment Court has regarded brothels as it would other developments, closely considering council controls to determine whether or not they are overly restrictive, and requiring hard and fast evidence of amenity impacts. For example, in Cresville Pty Ltd v. Sutherland Shire Council, ${ }^{2}$ the Court refused to apply the council's regulations separating 'brothels' from 'sensitive land uses' such as 'facilities that serve alcohol' by a distance of fifty metres. The Court noted that there was no link concerning adverse amenity impacts between premises that serve alcohol and sex shops. Commissioner Hussey observed that 'there is no apparent objective rationale for the separation distances, other than to provide an additional level of restrictions on these types of uses'. ${ }^{3}$ Whilst the owner was successful in this case and received development approval, appeals to the Land and Environment Court are expensive in terms of time and money, and success is not guaranteed. Accordingly, in many local government areas, brothel owners may either not submit a development application in the expectation of refusal, or accept a refusal without appeal. These highly restrictive regulations do not encourage brothel owners to seek authorisation, particularly if they have been operating without authorisation and without complaint. A development application would draw attention to their existence. This compels many brothels to operate outside the law.

The development of highly restrictive regulations is informed by a tendency of legislation, regulations, and Land and Environment Court decisions to draw upon a unitary category of 'brothel' for sex services premises. The current statutory definition of brothel in the Restricted Premises Act $1943:{ }^{4}$

2 Cresville Pty Ltd v. Sutherland Shire Council [2005] NSWLEC 498.

3 Cresville Pty Ltd v. Sutherland Shire Council [2005] NSWLEC 498 [42].

4 Restricted Premises Act I943 [NSW], s.2. 
'Brothel means premises:

(a) habitually used for the purposes of prostitution, or

(b) that have been used for the purposes of prostitution and are likely to be used again for that purpose, or

(c) that have been expressly or implicitly:

(i) advertised (whether by advertisements in or on the premises, newspapers, directories or the internet or by other means), or

(ii) represented, as being used for the purposes of prostitution, and that are likely to be used for the purposes of prostitution.

Premises may constitute a brothel even though used by only one prostitute for the purposes of prostitution.'

The majority of local councils with sex industry specific planning policies draw upon some form of this statutory definition, particularly that a brothel requires only one prostitute. The reliance upon a unitary definition to encapsulate all sex services premises is consistent with the conception of brothel as outlaw. The concept 'outlaw' does not differentiate between types of outlaw. Instead, it simply denotes criminality, with no distinction between the type or scale of illegality amongst outlaws. When we think of outlaws, the largest, most flamboyant, most threatening, are imagined. A similar effect informs much of the regulation of the sex industry. The catch-all category of 'brothel' is based on the type of sex services premises with potentially the largest amenity effects, that is, large-scale commercial brothels. To push the concept further, it seems much of the regulation of brothels is based upon those portrayed in westerns, with loud music, red velvet, and scantily clad women hanging out of windows - intertwining brothels with one of the most famous genres of outlaw culture.

This catch-all category of brothels has meant that it is very difficult for home occupation (sex services) to operate with development consent. These businesses offer sex services from the sex worker's home and are regarded as 'brothels' by state legislation and many local councils. The restriction of 'brothels' to commercial and/or industrial zones effectively prevents home occupations from operating legally. This has been exacerbated by the planning principles enunciated in Martyn v. Hornsby, which state that 'brothels' should 'not adjoin areas that are zoned residential, or be clearly visible from them,. ${ }^{5}$ These regulations effectively preclude home occupations (sex services) from operating with consent in areas with homes. In addition, many councils require applicants to place a sign outside the front of the property, explaining the nature of the proposed development. Whilst this may be appropriate for large-scale commercial brothels, when applied to home occupation (sex services) it would excite a great deal of community opposition and may well place the sex worker in danger. These kinds of planning requirements make it virtually impossible for home occupations (sex services) to apply for, let alone receive, development consent. This is problematic because it is estimated that home occupations (sex services) make up at least 40 percent of the sex industry (Brothels Taskforce, 200I). Accordingly, these planning regulations and principles ensure that a large proportion of the industry remains outside the law; that is, outlaws.

The Brothels Legislation Amendment Act 2007 [NSW] reiterated the conception of brothel as outlaw. This legislation expanded the powers of councils and the Land and Environment Court to close 'disorderly and unlawful brothels'. Under the Act, councils are able to make brothel closure orders that can be made effective within five working days rather than the previous 
twenty-eight days. Councils no longer require 'sufficient' complaints, but only one complaint to warrant a brothel closure order. ${ }^{6}$ Under the new legislation, the Land and Environment Court and local courts can now direct water, electricity and/or gas to be cut off to premises that have failed to comply with a brothel closure order. These reforms were aimed at brothel operators who 'persistently flout the law'.

The legislation reflects and reinforces a perception of brothels as inherently unlawful and disorderly. This is communicated particularly in the Environmental Planning and Assessment Act I979 [NSW], limiting the capacity of the Land and Environment Court to grant adjournments:

'The Court may not adjourn proceedings under S.I24(3) unless it is of the opinion that the adjournment is justified because of the exceptional circumstances of the case. The fact that it is intended to lodge a development application, or that a development application has been made, is not of itself an exceptional circumstance."

This subsection expresses the doubt that brothels would ever wish, or be able, to operate legally. A development application is regarded as a stalling tactic to prevent closure, with an owner going through the motions, rather than expressing a desire to operate legally. ${ }^{8}$

The reforms provide no encouragement to brothels that have been operating without authorisation and without the knowledge of the surrounding community to make a development application. If they applied for development approval, not only would they draw (unwanted) attention to themselves with the high likelihood of council refusal, but the local council would be able to impose closure orders and potentially shut off the utilities to the brothel whilst the Land and Environment Court is considering an appeal against council refusal.

The tendency to regard sex services premises as inherently unlawful was demonstrated in parliamentary debates on the Brothels Legislation Amendment Bill 2007 [NSW]. The Member for Pittwater, Rob Stokes, was concerned about the Land and Environment Court approving brothels after refusal by councils:

'In cases where councils have properly monitored developments and used their power to issue orders to shut down illegal brothels, the operators have simply turned around and sought a development application to legalise the land use, which the council understandably has refused. If the matter goes to court, the community is left to pay huge bills to fight illegal developments, which are often approved by the Court.' ${ }^{9}$

Stokes appears to be concerned not only about 'unlawful' brothels, but also that they might become 'lawful'. His argument suggests that any approval by the Land and Environment Court of brothels is misguided at best, and even with this approval, brothels remain 'illegal' developments.

The conception of brothels as outlaws, as inherently unlawful, is apparent in the lexicon of illegality expressed in the materials. Brothels are regarded as unlawful when they are not authorised by councils, regardless of whether or not they have tangible negative amenity impacts. In addition, authorised brothels are also labelled unlawful if they have disorderly impacts, or even in cases where the Land and Environment Court has approved a development in the face of council opposition. The Brothels Legislation Amendment Act 2007 [NSW] can be utilised to shut

6 Restricted Premises Act I943 [NSW], s. I7(2).

7 Environmental Planning and Assessment Act I979 [NSW], S.I24AB(2).

8 Whan, Steve (2007) NSW Parliamentary Debates, Legislative Assembly, 20 June 2007, p. I449; on behalf of Frank Sartor, Member for Rockdale, Minister for Planning, Minister for Redfern/Waterloo, Minister for the Arts.

9 Stokes, Rob (2007) Member for Pittwater, Hansard, NSW Parliamentary Debates, Legislative Assembly, 22 June 2007 , p. I646. 
down brothels which have never been authorised, but also those which are authorised but are disorderly. It is as though even when authorised, any possibility of lawfulness and order is at best temporary and contingent. There is an erasure of any distinction between failures to meet planning controls and criminality. This rhetoric of unlawfulness reinforces and reflects the concept of brothel as outlaw.

An alternative approach to regarding brothels as always already outlaws, is to instead conceptualise them as (potential) citizens; that is, as lawful subjects. The Disorderly Houses Amendment Act I995 [NSW] commenced the process of recognising brothels as legal subjects, and some local councils, such as the City of Sydney Council, have developed planning principles informed by the conception of sex services premises as citizens. The City of Sydney Council regulates inner-city suburbs, including Kings Cross, a famous 'red light district' with a high concentration of street-based sex workers (Perkins, I993). The Council has developed pragmatic planning principles aimed at regulating planning and amenity impacts rather than regarding brothels as inherently unlawful. The planning principles differentiate between sex services premises types based on size, nature and potential amenity impacts rather than the 'catch-all category' of brothel. Specific regulations are developed for different business types of brothels, safe house brothels, sex on premises venues, swingers' clubs, bondage and discipline parlours, and sex services (home occupations) premises. Home occupations (sex services) premises are permitted to operate without development consent, whilst larger sex services premises are required to submit a development application, including satisfying notification requirements and appropriate zoning. Pragmatic planning policies regarding sex services premises as (potentially) lawful subjects increase the ease and likelihood of sex services premises attaining a legal identity. Rather than devoting funds to identifying and excluding 'illegal' brothels, the City of Sydney Council assists in the process of sex services premises gaining authorisation. This can include identifying appropriate premises from which a business could operate with development consent, meeting appropriate zone requirements and highlighting the design needs of potential premises.

In local council areas where brothels are perceived as outlaws, such restrictive regulations are developed that it is very difficult for brothels to receive development consent, thus reinforcing the outlaw status of the sex industry. In contrast, regulations organised around the conception of sex services premises aid and assist the bestowal of legal status.

\section{Disorderly or orderly subjects?}

The concepts of outlaw and citizen invoke more than legal identity. The outlaw is literally outside the law, associated with disorder. The outlaw transgresses and violates the legal and moral order. In contrast, the citizen is a legal subject - subject to the law - with attendant rights and responsibilities. Accordingly, there are flow-on effects from attaining legal status that have implications for the business and surrounding community.

The conception of brothel as outlaw has been, and continues to be, reflected and reinforced in the regulation of the sex industry. This is particularly apparent in the long-term association of brothels with disorder. This is reflected colloquially, with the expression 'my house is like a brothel' used to denote untidiness and disorder. This association was reinforced and reflected at law in the case of Sibuse Pty Ltd v. Shaw, ${ }^{\text {IO }}$ where the Supreme Court declared that a brothel was a disorderly house whether it was well run or not. The legislation governing brothels was the Disorderly Houses Act I943 [NSW], and whilst the name of the legislation changed in 2002 to the Restricted Premises Act, the sections continue to refer to brothels as disorderly. This was

Io Sibuse Pty Ltd v. Shaw (1988) I3 NSWLR 98. 
augmented by the Brothels Legislation Amendment Act 2007 [NSW], which is aimed at 'unlawful and disorderly' brothels. This suggests that any shift away from the perception and expression of brothels as illegal and disorderly has been cosmetic at best.

I have previously considered the association of brothels with disorder and the implications at length (Crofts, 2007). I will focus on one of the themes of disorder - the idea of disorder as polluted and polluting. In her exploration of disorder in Purity and Danger, Mary Douglas considers the theme that 'dirt is dangerous' (I966/2002, p. x). Through an analysis of 'primitive' cultures, Douglas posited similarities between taboos and our own relationship with dirt. Taboos arose in response to ambiguous or anomalous concepts or things. Douglas asserts that our ideas about dirt are the modern equivalent of taboo: 'we denounce it by calling it dirty and dangerous; they taboo it.' Once we remove our knowledge of bacteria and hygiene, we are left with the old definition of dirt as 'matter out of place' (p. xi). Neither dirt nor taboo are absolute concepts, they are never unique, isolated experiences or events. Rather, they assume some kind of system, and contravention of that order.

Anomalous items such as those that are unique or instantiate properties of different classes are disturbing and become objects of pollution and taboo. Things that are acceptable or even attractive when in their proper place, can be polluting and dangerous when out of place. We might admire someone's beautiful hair, but if we find it in our soup it is disgusting. The construction of systems, the gestures of classifying, systematising and cleansing, are necessarily contingent. However, the central point is that both dirt and taboo offend. Dirt and taboo are matter out of place, anomalous or ambiguous, and challenge our systems and categories.

Douglas transposes our responses to dirt to people, things and ideas that are anomalous or ambiguous. Persons, things or ideas that cross lines, boundaries or margins of structures are polluted and polluting - they are disorderly and threaten disorder. In our fear and disgust of disorder we can seek to eliminate, punish, expunge or condemn the offending substance. These notions of disorder are applicable to outlaws. They have offended and offend against order, specifically the legal order. Through their actions and continued refusal to succumb to the law, they violate cherished values and threaten disorder. Historically, those who came in contact with the outlaw could be charged with the criminal offence of aiding and abetting. The outlaw fosters corruption and encourages and requires the violation and transgression of law. This notion of brothel as outlaw, as illegal and disorderly, creating a ripple effect of illegality and disorder, is expressed in different ways in legal documents.

The polluting effect of the outlaw is highlighted particularly by the association of brothels with corruption. One of the original reasons for legislative reforms in 1995 was the association of an illegal industry with police corruption - encouraging bribery by police and brothels. ${ }^{\text {II }}$ This potential for corruption by an illegal industry has now been extended to local councils, as demonstrated by the Independent Commission Against Corruption (ICAC) investigation of a council worker and his acceptance of bribes in the form of money and sexual services from illegal brothel owners and workers (ICAC, 2007). In exchange, the council worker would not investigate complaints against the brothel, or would warn them of upcoming investigations. Mr King, Counsel assisting the proceedings, articulated the opportunities generated for corruption by an illegal industry:

'In the past, operating relatively clandestinely and mostly in cash, the continued operation of brothels has always depended on the authorities, whether it be the police or local authorities failing to take action to investigate or prosecute. That inaction has no doubt frequently been

I I Paul Whelan, Minister for Police, Second Reading of Disorderly Houses Amendment Bill, Hansard, NSW Parliamentary Debates, Legislative Assembly, 20 September 1995, p. II87. 
the result of those engaging in the unlawful provision of sexual services being able to provide ongoing bribes to those charged with enforcement of the law and preparedness of the corrupt to accept those bribes or to extort payment where not offered to protect the activity. The corruption of individual public officers in this area has no doubt been a significant factor in their corruption in other areas to the more general harm of the community.

Being paid to turn a blind eye to the operation of a brothel can readily be extended to ignoring sexual servitude or the use or sale of prohibited drugs on those premises. Those prepared to engage in one criminal activity are frequently prepared to engage in other criminal activities. The past acceptance of bribes or engagement in extortion provides a powerful lever.' (ICAC, 2007)

This highlights the ripple effect of an illegal industry - it is polluting and contaminating undermining and fostering further violations of law.

The conception of brothels as outlaws generating lawlessness and disorder is also demonstrated in the belief that brothels are likely to attract more illegal elements to any area in which they operate. This was expressed clearly in Hang v. Strathfield Municipal Council, ${ }^{12}$ where, amongst other concerns, a petition signed by residents opposed to a brothel in an industrial area stated that 'the brothel would attract persons with a criminal record and increase crime in the area affecting both industrial and residential properties in that area'. In a Statement of Evidence in Huang $v$. Parramatta City Council, ${ }^{\mathrm{I}}$ Mamouzelos, the Strategic Crime and Corruption Officer of Parramatta City Council, asserted that 'brothels have significant impact upon crime and a tendency to generate criminality'. He then listed the 'typical crimes experienced within and around brothels' as armed robbery, assault, illegal drug supply/use, extortion/protection payments, drive-by shootings, illegal immigrants used as sex workers and people trafficking. ${ }^{\text {I4 }}$ This was supported by the Police Statement of Evidence:

'It is a known fact that brothels are targets of and even linked to organised crime syndicates. The most common links are through employment of illegal immigrants as sex workers and those to organised crime syndicates for protection or extortion. A new brothel paves the way for new opportunities.' ${ }^{\text {I5 }}$

Community objections to brothel development applications frequently cite fears that brothels will attract criminal elements, ${ }^{16}$ drug-taking pimps (Brothels Taskforce, 200I) and illegal immigrants. ${ }^{17}$ Brothels might attract 'undesirable people that may commit crime' and generate an increase in rubbish and litter. ${ }^{18}$ The objection that brothels lead to illegal parking and driving ${ }^{\mathrm{I} 9}$ demonstrates the way in which illegal behaviour is perceived to be contagious. The assumption is that people who work in or go to a brothel are immoral and engaging in unlawful activities, and are thus likely to break other moral and legal codes, such as parking and driving regulations. Just as an outlaw is perceived as contagiously dangerous, so too are brothels.

I 2 Hang v. Strathfield Municipal Council [2005] NSWLEC 99.

I3 Huang v. Parramatta City Council (forthcoming) Land and Environment Court roo85 of 2009.

I 4 Nicholas Mamouzelos (2009) 'Statement of Evidence: Brothel Development Proposal, Huang v. Parramatta City Council', Sydney: Parramatta City Council, pp. 4-5.

I5 Garth Neal (2009) 'Police Statement of Evidence Brothel Development Proposal: Huang v. Parramatta City Council', Sydney: NSW Police Force, p. 4.

I6 Marinos v. Ashfield Municipal Council [2005] NSWLEC 2.

I Hang v. Strathfield Municipal Council [2005] NSWLEC 99 [20].

I8 Guo v. Parramatta City Council [2007] NSWLEC 544.

I9 Hang v. Strathfield Municipal Council [2005] NSWLEC [20]. 
The perception that any person coming into contact with brothels will be polluted and polluting is particularly demonstrated in how brothel clients are regarded. The planning principles in Martyn v. Hornsby (2004) seek to discourage 'clients gathering or waiting on the street'. ${ }^{20}$ One of the grounds for refusing the development application for a brothel in Martyn v. Hornsby (2004) was its close proximity to a skincare college:

'The entrances are adjacent and it is likely that the students of the college would frequently encounter the brothel's clients on their way to and from classes. I do not want to judge whether this in itself would have a corrupting effect on them. However, it is likely, that some of the parents would not like the proximity of the brothel and would look for other colleges for their daughters. ${ }^{21}$

The assumption is that brothel clients are corrupt and corrupting. Through sheer physical proximity the brothel may pollute the students of the school. Objections to brothels are informed by the assumption that brothel clients will add nothing to a community, and may well commit or encourage crimes, a 'fear of unsavoury characters using the brothel or making victims of its customers. ${ }^{22}$ It is unclear from these objections whether the clients are potential victims or perpetrators of crime - there is simply a generalised association of brothels and their customers with crime.

The legislation reinforces the conception of brothels as polluted and polluting through an emphasis on the visibility of brothels. Under the Restricted Premises Act 1943 [NSW], ${ }^{23}$ a brothel can be closed if it is operating 'near or within view from a church, hospital, school or other place regularly frequented by children from residential or cultural activities'. This emphasis on the undesirability of the visibility of brothels is reiterated in the planning principles in Martyn $v$. Hornsby. Brothels 'should not be clearly visible from places where worshippers regularly gather'. Children and adolescents are 'impressionable' and accordingly it is 'undesirable' that they should be exposed to brothels. Thus, 'brothels should not adjoin, or be clearly visible from schools, educational institutions for young people or places where children and adolescents regularly gather. ${ }^{24}$ The Land and Environment Court has reiterated that brothels should not be 'prominent' in industrial zones, but should be discreet and there should be "no overt indications that it is being used as a brothel'. ${ }^{25}$

This emphasis upon the visibility of brothels has been imported from street sex legislation, the Summary Offences Act 1988 [NSW]. This expresses an assumption that the amenity impacts of street sex work and brothels will be the same. However, local councils and the Land and Environment Court can require structural design and management plans to ensure that neighbours do not see or hear what is going on inside a brothel, thus ensuring that these businesses have different amenity impacts from street sex work. Despite this, section I7(5)(a) of the Restricted Premises Act I943 [NSW] and the planning principles of Martyn v. Hornsby revolve around the idea that simply knowing that a brothel exists in your community, and being able to see the building, even if you cannot see what goes on inside it, is contaminating. ${ }^{26}$ This is based on an idea of contagion, with the activities inside the brothel infecting the bricks, mortar and roof of the entire

20 Martyn v. Hornsby Shire Council [2004] NSWLEC 6I4.

2 I Martyn v. Hornsby Shire Council [2004] NSWLEC 6I4 [20].

22 Davis v. Parramatta [2005] NSWLEC 474 [I9].

23 Restricted Premises Act I943 [NSW], s.I7(5)(a).

24 Martyn v. Hornsby Shire Council [2004] NSWLEC 6I 4 [I 8].

25 Joseph Vassallo v. Blacktown City Council [2004] NSWLEC 65 [I 7].

26 Martyn v. Hornsby Shire Council [2004] NSWLEC 6I4. 
building. It is almost as though the building is magically irradiated from within, polluting all who see it. This demonstrates the almost magical powers of pollution or 'matter out of place'. Two drops of sewage in a cask of wine will render the wine undrinkable, whereas two drops of wine in sewage will have no impact whatsoever (Miller, I997).

This idea that brothels are intrinsically disorderly subjects has been reinforced by the Brothels LegislationAmendment Act 2007 [NSW], aimed at facilitating the closure of 'unlawful and disorderly' brothels. An analysis of parliamentary debates indicates that the legislation was not aimed at tangible negative impacts. The focus of the debates was on unlawfulness, rather than negative impacts. This is highlighted by the reforms instigated by the legislation. Previously, under the Restricted Premises Act I943 [NSW], a council needed to receive 'sufficient' complaints to warrant a brothel closure order. Under the new reforms, the council need receive only one complaint before proceedings to obtain a brothel closure order may commence. This suggests that brothels are inherently unlawful and disorderly, and specific impacts are not necessary. Investigations into brothels tend to be instigated for a variety of different reasons. First, council workers may respond to a complaint or complaints made by a member of the public of negative amenity impacts or simply suspicions. Second, owners of authorised brothels might complain about unauthorised brothels that are operating in the area - motivated by a desire to remove the competition or a belief that they had paid a great deal of money to receive authorisation and it was unfair that a brothel was operating without these expenses. Third, council workers may ring advertisers to ascertain whether a business is proffering sexual services without authorisation (ICAC, 2007). In many cases, councils are not motivated to investigate unauthorised brothels due to complaints about tangible negative amenity impacts, rather they are informed by a perception that brothels are inherently illegal and disorderly and therefore undesirable.

The Brothels Legislation Amendment Act 2007 [NSW] was not introduced to address disorderliness in the sense of the specific negative amenity impacts of unauthorised brothels. Rather, the focus of the rhetoric around the legislation was upon fears of generalised dangers posed by brothels per se, ranging from drugs, disease and violence to the reduction of property prices. ${ }^{27}$ Just through their existence, brothels are thought to pose a danger to our community, even without any specific tangible impacts. Parliamentary debates, political promises and media reports often use the language of pestilence and disease. Illegal brothels have 'plagued our local neighbourhoods', ${ }^{28}$ 'pose a very real danger ${ }^{29}$ and are proliferating. Brothel developments 'encourage overspill of sleazy enterprise' and should be 'quarantined'. ${ }^{30}$ The legislation and regulation of brothels are thus informed by a fear of brothels as unlawful and dangerous. Like the outlaw, brothels offend against order, and foster and commit further illegalities.

In contrast, regarding the sex industry as a (potentially) legal subject has positive implications. Granting sex services premises legal status greatly reduces (if not removes) the opportunity for police and local council corruption due to the absence of any leverage for bribery. Some illegal elements may remain in the sex industry, but the opportunities for massive profits from black market services are greatly reduced by a legal industry. The underlying idea is that when sex services premises are legalised, they can be regulated. Legal status brings with it accountability, rights and responsibilities. Until the reforms of I995, there was no encouragement for brothels to be well run or orderly. In fact, paraphernalia associated with a well-run brothel, such as safe-sex equipment, could be disadvantageous as it could be relied upon as evidence that an unauthorised brothel was operating.

27 Rob Stokes (2007), NSW Parliamentary Debates, Legislative Assembly, 22 June 2007, p. I646.

28 Rob Stokes (2007), NSW Parliamentary Debates, Legislative Assembly, 22 June 2007, p. I648.

29 Don Harwin (2007), NSW Parliamentary Debates, Legislative Assembly, 22 June 2007, p. 2085.

30 Mark Makhoul v. Parramatta City Council [2006] NSWLEC 567 [35]. 
Running sex services premises as a legitimate business imports legal frameworks that have been developed over long periods of time. As citizens, sex services premises are required to pay and administer taxes. ${ }^{3 \mathrm{I}}$ Councils are able to impose health and safety requirements, such as requiring a shower and basin in each room, and the development of security measures. Development applications must include a statement of environmental effects and management plans. Limits can be imposed on operating hours, group bookings and a prohibition on serving intoxicated clients. The Land and Environment Court has demonstrated a preference for good structural design of brothels to reduce noise and negative amenity impacts, rather than relying solely upon management plans. All of these aspects are required and imposed by becoming part of the existing legal framework. This extends to issues such as workers' rights, taxes, health and safety, and discrimination law. A legalised industry also facilitates outreach programmes by health professionals. As a consequence of the good regulation of sex services premises in the City of Sydney over more than a decade, the number of objections to brothel development applications has dropped dramatically. For example, a development application from an existing brothel in the City of Sydney area received only one objection and this related only to general concerns of graffiti in the area. ${ }^{32}$ The local community has faith that sex services premises will be well regulated and subject to the law. The City of Sydney has also demonstrated that it is willing to pursue authorised sex services premises that are not adhering to planning requirements. Thus in DeCue, ${ }^{33}$ the council successfully applied to the Land and Environment Court for an erotic massage parlour that had resulted in public antisocial behaviour, such as urinating in vegetation and propositioning neighbours, to be shut down. Giving sex services premises legal status results in a capacity to regulate and ensure that they are orderly subjects.

The granting of legal status imports a right to governmental protection of liberty, safety and property. This means that sex services premises and their workers and clients are able to turn to the law for protection. In Huang v. Parramatta, the Senior Constable of Police Garth Neal's Statement of Evidence asserts that an existing authorised brothel near the proposed brothel had been the subject of biker gang threats accompanied by promises of 'protection'. ${ }^{34}$ The officer relies upon this as evidence of the inherent unlawfulness of brothels. In contrast, I regard this as demonstrating an advantage of legal status, albeit in its infant form. Rather than succumbing to biker gang threats, the brothel owner was able to, and did, report the threats to the police and seek protection from existing legal institutions. The bestowing of lawful identity and thus legal protection is also demonstrated in the treatment and regard of individual sex workers. Research has consistently shown that sex workers experience high level of violence and are more at risk of harm than other citizens (City of Sydney 2005; Prior 2007). Outlaws are regarded as a threat to the community, and many may think that they are deserving of violence. Moreover, outlaws have no avenues for protection against violence; they are outside the law. Legal status ensures that legal avenues are available for protection and redress. Moreover, it facilitates research into how best to protect sex workers, including the good design of brothels and the introduction of 'safe houses' (City of Sydney, 2005). Safe houses are privately owned commercial premises that provide short-term room rental to clients to enable the provision of sexual services by a sex worker. These safe houses provide workers with a cheap, easily accessible, legal, clean and safe environment to

3 I Taxation is administered by the federal government, accordingly payment of taxes is a separate question from whether or not a sex services premises is authorised by a local council.

32 Information received from the City of Sydney, Sex Industry Policy Officer.

33 Sydney City Council v. DeCue [2006] NSWLEC 763.

34 Garth Neal (2009) 'Police Statement of Evidence Brothel Development Proposal: Huang v. Parramatta City Council', Sydney: NSW Police Force, p. 5 . 
service their clients. This means that workers have less need to risk their own safety by getting into a client's car or conducting services in other isolated private venues (City of Sydney, 2005).

In summary, bestowal of legal status imports an existing legal framework of rights and responsibilities. With legalisation comes the opportunity to regulate, ranging from workers' rights, administering and paying taxes, and occupational health and safety, to imposing planning requirements that minimise negative amenity impacts. Moreover, with legal status comes the opportunity to make claims upon the legal system for protection, a possibility denied the outlaw. In contrast, the conception of brothels as outlaws results in the restrictive regulation of brothels as disorderly subjects, breaching the legal and moral order, generating corruption and lawlessness.

\section{Expulsion versus membership}

The metaphor of brothel as outlaw reflects and reinforces a desire to expel and exclude. The outlaw is polluted and polluting, a threat to the community, undermining and violating cherished boundaries. In our fear and disgust of the outlaw we seek to punish, eliminate and expunge, relying on cleansing gestures to shore up and reaffirm the threatened order. This can be compared with our perception of citizens, who are seen as part of an orderly community, capable of making a contribution.

The history of brothels is one of elimination and expulsion. Despite reforms, many local councils continue to regard and regulate brothels as inherently unlawful and disorderly. Many local councils exclude brothels from residential zones, and this has been confirmed by the Land and Environment Court planning principles, stating that 'Brothels should not adjoin areas that are zoned residential, or be clearly visible from them. ${ }^{35}$ Given that a large proportion of the sex industry is made up of home occupations, this approach means that a large proportion of the sex industry is unable to receive authorisation in most local councils, and risks closure or threats and blackmail (ICAC, 2007).

The desire to expel brothels from local government areas has also been highlighted in commercial zones. Many local councils do not permit brothels in residential or commercial zones. Those that do permit brothels in commercial zones tend to require the brothel to be on the first floor or above, but then impose strict disability access and parking requirements that are not required of other businesses. Objections in the Land and Environment Court have focused on the potential for brothels to contaminate commercial zones, lowering property values and frightening away customers. For example, in Cresville Pty Ltd v. Sutherland Shire Council, ${ }^{36}$ the council objected to a sex shop development application arguing that the public could find the 'use offensive and not shop in the Centre or at nearby retailers, which could result in the loss of expenditure'. It was claimed that even though the shop was on the first floor of a commercial business, it could create the impression of a 'red light' district.

In a desire to expel brothels from the community, many local councils have restricted brothels to industrial zones. Even here, the desire to expel and erase brothels has been expressed. For example, Parramatta City Council has imposed a 200-metre restriction on brothels from the nearest residential dwellings, greatly restricting the industrial areas available (Parramatta LEP $200 \mathrm{I}^{37}$ ). Councils have expressed a desire to 'reduce the prominence of brothels', ${ }^{38}$ screening the brothel, prohibiting signs and attempting to reduce late night lighting, to ensure passers-by would

35 Martyn v. Hornsby Shire Council [2004] NSWLEC 6I 4 [I8].

36 Cresville Pty Ltd v. Sutherland Shire Council [2005] NSWLEC 298 [27].

37 Parramatta City Council Local Environmental Plan 200I.

38 Joseph Vassallo v. Blacktown City Council [2004] NSWLEC 65, I 5. 
not be alerted to its existence. The major way in which councils attempt to expel brothels from industrial zones is through security concerns. For example, in their Statement of Evidence in Huang, police asserted:

'... the proposal is within a small industrial estate. After business hours the industrial estate has little pedestrian or vehicular traffic and low levels of lighting. This causes a sense of isolation and invites crime, ranging from minor anti-social behaviour incidents to major crimes such as armed robbery ... The combination of isolation, multiple escape routes in addition to the distance of the industrial estate from responding police stations increasing response times in significant risk of crime.'[sic] $]^{39}$

The siting of brothels in industrial zones can be problematic. Industrial zones tend to be poorly serviced at night, with no public surveillance, poor lighting and little or no public transport. Only the very large commercial brothels are capable of meeting the expense of added security, notification requirements and remodelling of buildings. This in turn confirms the conception of sex services premises as large businesses with serious amenity impacts warranting restrictive regulation. Councils insist that brothels may only exist in industrial zones, but then express concern that this may lead to security risks to people and businesses, and therefore refuse brothel applications. This reasoning suggests that brothels are literally matter out of place - there is no place in which they can exist in an orderly way; they remain outlaws. The notion of brothel as outlaw, worthy of expulsion and exclusion, has been expressed in the Brothels Legislation Amendment Act 2007 [NSW].

The alternative approach of regarding sex services premises as citizens encourages a different way of imagining the regulation of sex services premises. Douglas has recognised that our organising structures are contingent. Our responses to disorder can be negative or positive. In our fear and disgust of disorder we can seek to eliminate, punish and expunge the offending substance, or we can change our systems of order, at the individual or structural level, to incorporate and accept the ambiguous and anomalous. Taboo and dirt are regarded as dangerous in part because of their potential for instigating change (Douglas, I966/2002). Rather than outlaws that should be expelled from the community, sex services premises can be regarded as legitimate businesses, members who are capable of contributing to the community.

Research has indicated that home occupations (sex services) have little to no negative amenity impact. Most people are unaware that they have been living next to a home occupation (sex services). Home occupations (sex services) need to be discreet - to keep clients and also for personal safety (City of Sydney, 2005). Accordingly, provided people are not informed that they are living near or next to a home occupation (sex services), they are unlikely to ever become aware of its existence. Home occupations (sex services) could and should be regulated like any other home occupations, authorised to operate without consent provided that they have minimal amenity impacts. Moreover, rather than excluding brothels from commercial zones due to fears that it may lead to a loss of expenditure, sex services premises can be regarded as attracting customers to the area. ${ }^{40}$ In industrial zones, rather than perceiving brothels as increasing crime, they could be regarded as offering natural surveillance after hours.

The pursuit of 'illegals' in some councils does not encourage investment in the business or community. The alternative approach of regarding and regulating sex services premises as legitimate has led to investment of time and money in these businesses. These owners invest in the

39 Garth Neal (2009) 'Police Statement of Evidence Brothel Development Proposal: Huang v. Parramatta City Council', Sydney: NSW Police Force, p. I.

40 Cresville Pty Ltd v. Sutherland Shire Council [2005] NSWLEC 298. 
building - often custom designing or renovating - in order to meet council requirements and to attract customers. They plan to remain in the area for long periods of time, and thus as a matter of business wish to maintain good neighbourly relations. A richer conception of citizenship emphasises community, the idea that successful realisation of private goals depends on the vitality of a common life (Carter and Stokes, 2002). Whether due to pragmatic business or a broader notion of membership and belonging, legal status encourages businesses to invest in the community. Brothels have open days to dispel myths of disorderliness, charity days and give to charities, highlighting that they are contributing members of the community (O‘Brien, 2006).

\section{Conclusion}

Historically, sex services premises were regarded and regulated as illegal and disorderly entities; they were policed as outlaws. The Disorderly Houses Amendment Act I995 [NSW] bestowed legal status, providing an opportunity to regulate sex services premises as legal subjects. Despite these reforms, in many areas brothels continue to be regulated more restrictively than other businesses. This is because, for many, brothels continue to be perceived as outlaws. This conception of brothel as outlaw has structured and reinforced the understanding and regulation of the sex industry. Brothels continue to be regarded as inherently unlawful, disorderly and hence warranting and requiring exclusion from the community. This conception is displayed in some of the legislation, regulations, and Land and Environment Court decisions. Councils have developed highly restrictive planning policies in an effort to exclude brothels from the local government area, confirming the illegality of sex services premises. The Land and Environment Court has developed restrictive planning principles, reflected and reinforced by the Brothels Legislation Amendment Act 2007, [NSW] encouraging and facilitating excluding 'unlawful and disorderly' brothels.

The Disorderly Houses Amendment Act 1995 [NSW] introduced an alternative way of conceiving brothels: as lawful subjects. Some local councils and Land and Environment Court decisions have taken up the opportunity to regard and regulate sex services premises according to orthodox planning concerns. This shift demonstrates how concepts shape our perceptions and behaviour. The conception of sex services premises as citizen imports an existing legal framework, with associated accountabilities, rights and responsibilities. With legalisation comes regulation. Rather than being perceived as negative and disorderly, sex services premises can be regarded and regulated as members of the community, as contributors rather than violators. This shift in conception results in people viewing sex services premises differently, experiencing them differently and regulating them differently.

\section{References}

ARMS, Adam (1999) 'Metaphor, Women and Law', Hastings Women's Law Journal Io: 257-86.

BelL, David (2000) The Sexual Citizen: Queer Theory and Beyond. Cambridge: Polity Press.

BeLl, David and BINNIE, Jon (2000) The Sexual Citizen: Queer Politics and Beyond. Cambridge: Polity Press. BROTHels taskforce (200I) Report of the Brothels Taskforce. Sydney: Department of Planning, NSW Government.

CITy Of Sydney (2005) Home Occupation Sex Service Premises Research Project: Final Report. Sydney: City of Sydney.

CARTER, April and stokes, Geoffrey (eds) (2002) Democratic Theory Today: Challenges for the Twenty First Century. Cambridge: Blackwell Publishers.

CROFTs, Penny (2007) 'Brothels and Disorderly Acts', Public Space: The Journal of Law and Social Justice I: I-39. 
DEPARTMENT OF URbAN AFFAirs AND PLANNing (I996) 'Council Circular - Planning Controls of Brothels', I6 July, NSW Government.

Douglas, Mary (1966/2002) Purity and Danger: An Analysis of the Concepts of Pollution and Taboo. London: Routledge and Kegan Paul.

ніввіттs, Bernard (I994) 'Making Sense of Metaphors: Visuality, Aurality and the Reconfiguration of

American Legal Discourse', Cardozo Law Review I6: 229-356.

indePendent Commission against corruption (ICAC) (2007) Parramatta City Council Investigation into

Solitication and Bribery, available at www.icac.nsw.gov.au/index.cfm?objectID $=42 \mathrm{E} 39 \mathrm{~B} 85-\mathrm{BAB}$ -

FDD 5-EF2 ICA9D2AogCF6C\&flushcache $=\mathrm{I}$

LAKoff, George and johnson, Mark (I980) Metaphors We Live By. Chicago: University of Chicago Press. loughlan, Patricia (2006) 'Pirates, Parasites, Reapers, Sowers, Fruits, Foxes Ö The Metaphors of Intellectual Property', Sydney Law Review 28: 2 I I-26.

miller, William (I997) The Anatomy of Disgust. Cambridge, MA: Harvard University Press.

MOON, Jeremy, CRANE, Andrew and matTen, David (2005) 'Can Corporations be Citizens? Corporate

Citizenship as a Metaphor for Business Participation in Society', Business Ethics Quarterly I5(3): 429-53.

O’BRIEn, Juliette (2006) 'Sex Businesses Donating to Charity', Swerve, available at http://studentwork. hss.uts.edu.au/ojı/swerveo6/sex_businesses/page2.html

PERKINS, Roberta (I993) 'Street Prostitution and Its Manipulation by Law in New South Wales' in

Patricia Weiser Easteal and Sandra McKillop (eds) Women and the Law Conference, 24-26

September 1991. Canberra: Australian Institute of Criminology, 99-I08.

PRIOR, Jason (2007) Safety Incident Report Sydney. Sydney: Elton Consulting.

RubensteIn, Doris (2004) The Good Corporate Citizen. Hoboken NJ: John Wiley and Sons.

THORnbuRG, Elizabeth (I995) 'Metaphors Matter: How Images of Battle, Sport and Sex Shape the

Adversary System', Wisconsin Women's Law Journal Io: 225-82.

TSAI, Robert (2004) 'Fire, Metaphor and Constitutional Myth-Marking', Georgia Law Journal 93:

I8I-24I.

ZADEK, Simon (2007) The Civil Corporation: The Economy of Corporate Citizenship. London: Earthscan. 
Reproduced with permission of the copyright owner. Further reproduction prohibited without permission. 